\title{
Flora of Singapore precursors, 14. Notes on Apocynaceae
}

\author{
M. Rodda \& D.J. Middleton \\ Singapore Botanic Gardens, National Parks Board, \\ 1 Cluny Road, 259569 Singapore \\ rodda.michele@gmail.com
}

\begin{abstract}
Lectotypes are designated for 28 names of Apocynaceae, seven of which are second-step lectotypifications. Two names are neotypified, Leptostemma hirsutum Blume is designated as the type of the genus Leptostemma Blume, and a new combination in Secamone R.Br. is coined for Genianthus maingayi Hook.f.
\end{abstract}

Keywords. Genianthus, lectotype, neotype, Secamone

\section{Introduction}

During the preparation of the account of Apocynaceae for the Flora of Singapore, types of all taxa occurring in Singapore and their synonyms were verified. For those taxa in the informal groups known as the rauvolfioid and apocynoid Apocynaceae (corresponding to the family before the Asclepiadaceae was included), most of the typifications were already done in previous works (see Middleton, 2007, 2011). Some of these require refinement. In addition, numerous asclepiad Apocynaceae names require typification or corrections to earlier typifications.

The second part of the paper addresses the generic placement of Genianthus maingayi Hook.f. The status of the Asian genera Genianthus Hook.f. and Toxocarpus Wight \& Arn. and their relationships with the widespread Secamone R.Br. (Old World tropics and subtropics) are still to be clarified. However, Klackenberg (2001, 2004) considered the three genera congeneric. His argument was based on the observation that even though the three genera can be separated morphologically in Asia, Secamone in Madagascar is extremely variable and Madagascan species include characters such as the dorsiventrally compressed corona lobes and the long style heads, also observed in Genianthus and Toxocarpus. Even though no extensive phylogeny has been published on Asian Secamonoideae, the phylogeny published in Surveswaran et al. (2014) includes one species of Toxocarpus, T. wightianus Hook. \& Arn., thatis included within a Secamone clade. Singapore has one species of Toxocarpus, Toxocarpus griffithii Decne. and one species of Genianthus, Genianthus maingayi Hook.f. These will be treated in the Flora of Singapore as species of Secamone. The combination Secamone griffithii (Decne.) Klack. is already published, while a new combination in Secamone is needed for Genianthus maingayi. 


\section{Materials and methods}

The present paper is based on the examination of specimens at B, BM, E, G, K, KEP, L, P and SING as well as on JSTOR Global Plants (https://plants.jstor.org/, accessed on 19 Jan 2019). All names have been compared to the data in the International Plant Names Index (IPNI; http://www.ipni.org/, accessed on 19 Jan 2019) and TROPICOS (http://www.tropicos.org/, accessed on 19 Jan 2019). All protologues and type citations have been checked. Lectotypes are designated for names where the protologue did not clearly mention a single type specimen with a reference to the institution in which it was deposited, strictly applying Art $9.1 \& 9.3$ of the ICN (Turland et al., 2018). All names are listed in alphabetical order, with the accepted name indicated in bold.

\section{Typifications}

1. Alstonia macrophylla Wall. ex G.Don, Gen. Syst. 4: 87 (1837). - TYPE: India, Hort. Bot. Calcutta, N. Wallich 1648 (lectotype K-W [K001113713], first step designated by Huber (1973), second step designated here by Middleton; isolectotypes K-W [K001113714], P [P00492394]).

In earlier literature, Wallich 1648 in Kew was referred to incorrectly as a 'holotype', correctable to an effective lectotypification and cited as such in Middleton (2007, 2011). However, there are two specimens of Wallich 1648 in K-W so a second step is required.

2. Alyxia coriacea Wall. in Roxb., Fl. Ind. 2: 541 (1824). - TYPE: Peninsular Malaysia, Penang, N. Wallich 1610 (lectotype K-W [K001113585], first step designated by Leeuwenberg (2003), second step designated here by Middleton; isolectotypes BM [BM000508455], G [G00169666], K-W [K001113584]).

= Melodinus orientalis Blume

A lectotype was designated by Leeuwenberg (2003) but he did not distinguish between the two specimens of Wallich 1610 in K-W. Hence a second-step lectotypification is here required. Leeuwenberg (2003) placed this name in synonymy of Melodinus coriaceus Oliv. but both names were treated as synonyms of Melodinus orientalis Blume by Middleton (2007, 2011). Alyxia coriacea Wall. and Melodinus coriaceus Oliv. are not homotypic, despite sharing a specific epithet, which is why Melodinus coriaceus is not the correct name for the species even though Alyxia coriacea was published earlier than Melodinus orientalis.

3. Collyris major Vahl, Skrift. Nat. Selsk. Kiobenh. 6: 460 (1810). - Dischidia major (Vahl) Merr., Interpr. Herb. Amboin. 437 (1917). - TYPE: Malaysia, Malacca or 
Selangor, J.G. Köenig s.n. (lectotype C, first step designated by Panigrahi (1986), second step designated here by Rodda, excluding concave leaves belonging to a different species).

Dischidia major (Vahl) Merr. was typified by Panigrahi (1986) based on a Köenig collection in $\mathrm{C}$. The specimen is, however, a mixed collection as it also includes concave leaves of a different species. The lectotypification is, therefore, refined here to exclude the elements not belonging to Dischidia major.

4. Cynanchum pauciflorum R.Br., Mem. Wern. Nat. Hist. Soc. 1: 45 (1810), nom. illeg. - Cynoctonum pauciflorum Decne. in A.DC., Prodr. 8: 528 (1844), nom. illeg. - Periploca tunicata Retz., Observ. Bot. (Retzius) 2: 15 (1781). - Vincetoxicum tunicatum (Retz.) Kuntze, Revis. Gen. P1. 2: 423 (1891). - Cynanchum tunicatum (Retz.) Alston in Trimen, Hand-Book Fl. Ceylon vi. Suppl. 194 (1931). - TYPE: "E Tranquebaria misit optimus König” s.d., J.G. Köenig s.n. (lectotype LD [LD1731246], designated by Fischer (1932)).

Brown (1810) included Periploca tunicata Retz. in synonymy of Cynanchum pauciflorum R.Br. making it illegitimate under ICN Art 52.1 (Turland et al., 2018). Likewise, Decaisne (1844) included Periploca tunicata in synonymy of Cynoctonum pauciflorum Decne. making it illegitimate. Both names are automatically typified with the type of Periploca tunicata Retz. However, for Cynanchum pauciflorum Brown (1810) also mentioned a specimen in the Banks herbarium that can be identified as Societas Unitatis Fratrum s.n. (BM) [BM001209604]. This specimen is Cynanchum tunicatum. Similarly, Decaisne (1844) indicated that he based Cynoctonum pauciflorum Decne. on material examined in the Paris herbarium (v.s.h. Mus. par). Wight 1550 [P03872472] is identified as "Cynoctonum pauciflorum Dne!", likely in Decaisne's hand, which is likely to be the material indicated in the publication. In P there are also two further duplicates of Wight 1550 [P03872473, P03872474]. These specimens are also Cynanchum tunicatum.

5. Cynoctonum formosanum Maxim., Bull. Acad. Imp. Sci. Saint-Pétersbourg 23: 370 (1877). - Cynanchum formosanum (Maxim.) Hems1., J. Linn. Soc., Bot. 26: 106 (1889). - Vincetoxicum formosanum (Maxim.) Kuntze, Revis. Gen. P1. 2: 424 (1891). - Cyathella formosana (Maxim.) C.Y.Wu \& D.Z.Li, Acta Phtyotax. Sin. 28: 464 (1990). - TYPE: Taiwan, Tamsuy, 1864, R. Oldham 333 (lectotype LE [LE01036909], designated here by Rodda; isolectotypes K [K000872722], P [P032523], S [S-G1845]). = Cynanchum ovalifolium Wight, fide Liede (1999)

The type of Cynoctonum formosanum Maxim. is Oldham 333. The LE duplicate is fertile and well preserved and bears manuscript notes likely by Maximowicz. It is therefore here selected as lectotype for Cynoctonum formosanum. 
6. Cynoctonum zollingeri Miq., Fl. Ned. Ind. 2: 479. (1857). - Cynanchum zollingeri (Miq.) Boerl., Handl. Fl. Ned. Ind. 2: 436 (1899). - TYPE: Indonesia, Java?, H. Zollinger 2416 (lectotype P [P032525], designated here by Rodda; isolectotype BM [BM000053517]). = Cynanchum ovalifolium Wight, syn. nov.

Liede (1999), in her revision of Malesian Cynanchum, did not include Cynanchum zollingeri (Miq.) Boerl. The type collection Zollinger $2416(\mathrm{P})$ is identified by Liede as Cynanchum ovalifolium, a widespread and rather variable species. Her identification is also confirmed here. Although it was Zollinger's private set that was lent to Miquel and which is now in P, Zollinger's specimens are widely distributed (Van SteenisKruseman, 1950) and it cannot be ruled out that Miquel might have seen and based his description on other duplicates of this collection. The P duplicate of Zollinger 2416 is therefore designated as lectotype for Cynanchum zollingeri.

7. Dischidia bengalensis Colebr., Trans. Linn. Soc. London 12: 357 (1818). - TYPE: Trans. Linn. Soc. London 12: 357, t.15 (1818) (lectotype designated here by Rodda)

No specimen is mentioned in the protologue of Dischidia bengalensis Colebr. and likely the description is based on a cultivated plant "Native of Silhet ... and thence introduced into the botanical garden at Calcutta by Mr M.R. Smith". The illustration published together with the protologue (t.15) is the only original material found and is therefore designated as lectotype.

8. Dischidia borneensis Becc., Malesia 2: 262 (1886). - TYPE: Malaysia, Sarawak, Kuching, Dec. 1865, O. Beccari PB793 (lectotype FI ([FI008057] mounted over two sheets, designated here by Rodda; isolectotypes K [K000911025], M [M0031479]). = Dischidia albiflora Griff. fide Rintz (1980b).

Types of Beccari's taxa are generally considered to be in FI. However, Dischidia borneensis Becc. was published before Beccari's specimens were given to FI and duplicates were distributed. The only material indicated in the protologue of Dischidia borneensis Becc. is Beccari PB793 and the FI duplicate is designated as lectotype. This specimen, mounted on two sheets (indicated as Collezioni Beccari 6963A and 6963B), is the most complete and best preserved duplicate.

9. Dischidia borneensis Becc. var. pilosa Becc., Malesia 2: 263 (1886). - TYPE: Malaysia, Sarawak, Undup, Batang-Lupar, O. Beccari s.n. (lectotype FI [FI013046], designated here by Rodda). = Dischidia albiflora Griff. fide Rintz (1980b).

As indicated above for Dischidia borneensis, a lectotype needs to be selected also for Dischidia borneensis Becc. var. pilosa Becc. Beccari did not indicate any collection 
number for Dischidia borneensis var. pilosa, only "Undup nella Prov. del BatangLupar, in Sarawak, Borneo". Specimen Beccari s.n. [FI013046] was collected in Undup and is identified in Beccari's hand as Dischidia borneensis var. pilosa and is therefore selected as lectotype.

10. Dischidia brunoniana Griff., Calcutta J. Nat. Hist. 8(29): 85 (1847). - TYPE: Myanmar, Mergue, W. Griffith s.n., Kew distribution 3872 (lectotype K [K000911063], designated here by Rodda). = Dischidia hirsuta (Blume) Decne, fide Rintz (1980b).

The type of Dischidia brunoniana Griff. was indicated as "Mergue. Inter Rhizophoreis. Ins. Madamacam Palor prope". Specimen Griffith s.n., Kew distribution 3782 [K000911063] bears a manuscript label "Mergue" and is therefore here designated as lectotype.

11. Dischidia coccinea Griff., Not. P1. Asiat. 4: 45 (1854). - TYPE: Malaysia, Malacca, W. Griffith s.n., Kew distribution 3780 (lectotype K [K000911056], designated here by Rodda). = Dischidia cochleata Blume, fide Rintz (1980b).

The type of Dischidia coccinea Griff. was indicated as "In arbor Terebinthae, Malacca". Specimen Griffith s.n., Kew distribution 3780 [K000911056] bears a manuscript label "Malacca" and is therefore here designated as lectotype.

12. Dischidia oiantha Schltr., Fragm. Fl. Philipp. 1: 127 (1904). - TYPE: Philippines, Busuanga, Sep 1910, E.D. Merrill 7200 (neotype B [B100003245], designated here by Rodda; isolectotype K [K000911004]).

The type of Dischidia oiantha Schltr., Warburg 12252, was deposited in B (now destroyed). No duplicates have been located and therefore Merrill 7200 (B), also lectotype of Dischidia tonsa Schltr., a synonym of $D$. oiantha, is chosen as neotype for D. oiantha.

13. Dischidia orbicularis Decne. in A.DC., Prodr. 8: 632 (1844). - TYPE: Timor (lectotype P [P00218805], designated here by Rodda; isolectotype P [P00218806]). = Dischidia nummularia R.Br., fide Rintz (1980b).

Decaisne indicated that he had examined Dischidia orbicularis Decne. at P "v.s. h. Mus. par." Between the two syntypes of Dischidia orbicularis currently found at P [P00218805 \& P00218806], [P00218805] is a better collection and is here selected as lectotype. 
14. Dischidia pseudobenghalensis Costantin in Lecomte, Fl. Indo-Chine 4: 148 (1912). - TYPE: Vietnam, Tay Ninh Province, Deon ba mountain, 1866, L. Pierre 4521 (lectotype P [P00639856], designated here by Rodda; isolectotype P [P00218978, P00639857]). = Dischidia bengalensis Colebr., fide Rintz (1980b).

The type of Dischidia pseudobenghalensis Costantin was indicated as "mont Deon-ba, province de Tay-ninh (Pierre)". Among the three syntypes located in P, [P00639856] is a well-preserved fertile specimen and is selected as lectotype. Three further specimens of Pierre 4521 [P00218979, P00639859, P00639859] are not isolectotypes as their collection locality is Baria, mount Dinh.

15. Dischidia shelfordii H.Pearson, Ann. Bot. 17: 617 (1903). - TYPE: Borneo, Sarawak, Kuching, 31 Dec 1902, Shelford s.n. (lectotype K [K000911021], first step designated by Rintz (1980b), second step designated here by Rodda; isolectotypes K [K000911022], one not barcoded). = Dischidia complex Griff., fide Rintz (1980b).

Rintz (1980b) indicated the type of Dischidia shelfordii H.Pearson as "Borneo, Sarawak. Kuching, Shelford s.n. (K)" without specifying which one of the three duplicates he intended. The K specimen [K000911021] is therefore designated as lectotype, second step.

16. Dischidia spatulata Blume, Bijdr. Fl. Ned. Ind. 16: 1060 (1826). - Dischidia bengalensis var. spatulata (Blume) Kuntze, Revis. Gen. P1. 2: 419 (1891). - TYPE: Java, Blume s.n. (lectotype L [L. 2725227], designated here by Rodda). = Dischidia bengalensis Colebr., fide Rintz (1980b).

Blume indicated the locality of Dischidia spatulata Blume as "ad litora insulae Nusae Kambangae". No specimens from L bear a collection label matching Blume's description. However, one specimen [L.2725227] can be identified as original material of Dischidia spatulata as it was annotated by Blume "Dischidia spatulata Bl." and is here selected as lectotype.

17. Dischidia timorensis Decne., Nouv. Ann. Mus. Par. 3: 377, t. 17 (1834). - TYPE: Timor-Leste, Guichenot s.n. (lectotype P [P00639926], designated here by Rodda). = Dischidia major (Vahl) Merr. fide Rintz (1980b).

No material seen was indicated in the protologue of Dischidia timorensis Decne. Three sheets from Timor annotated in Decaisne's hand are available in P [P00639926, P00639928, P00639927]. Only [P00639926] (Guichenot s.n.) can be linked to the protologue as it is clearly the specimen used for Ann. Mus. Par. 3: 377, t. 17 and is annotated "tab". 
18. Dischidia tonsa Schltr., Repert. Spec. Nov. Regni Veg. 13: 558. (1915). - TYPE: Philippines, Busuanga, Sep 1910, E.D. Merrill 7200 (lectotype B [B100003245], designated here by Rodda; isolectotype K [K000911004]). = Dischidia oiantha Schltr.

Dischidia tonsa Schltr. was described based on Merrill 7200. The duplicate in B is the best preserved and is therefore selected as lectotype.

19. Echites fragrans Moon, Cat. P1. Ceylon 20 (1824). - Chonemorpha fragrans (Moon) Alston, Ann. Roy. Bot. Gard. (Peradeniya) 11: 203 (1929). - TYPE: Illustration in Rheede, Hort. Malab. 9: t.5 (1689), lectotype designated here by Middleton.

In previous publications where the type was cited, two plates from the Hortus Indicus Malabaricus (Rheede, 1689) were given. Here, the name is lectotypified on one of them, an illustration of flowering material.

20. Epigynum ridleyi King \& Gamble, J. Asiat. Soc. Bengal, Pt. 2, Nat. Hist. 74(2): 502 (1908). - TYPE: Peninsular Malaysia, Selangor, Rawang, H.N. Ridley 7567 (lectotype SING [SING0040345], designated here by Middleton; isolectotype K [K000894489]).

In Middleton $(2007,2011)$ the specimen designated here as lectotype was incorrectly referred to as a holotype.

21. Epigynum forbesii King \& Gamble, J. Asiat. Soc. Bengal, Pt. 2, Nat. Hist. 74(2): 503 (1908); Turner, Gard. Bull. Singapore 45 (1993) 35. - TYPE: Sumatra, near Bijin Telok, H.O. Forbes 3236 (lectotype K [K000894487], designated here by Middleton). = Epigynum ridleyi King \& Gamble

In Middleton $(2007,2011)$ the specimen designated here as lectotype was referred to as a holotype. It is uncertain as to whether there are any duplicates of this collection but a lectotypification of the $\mathrm{K}$ specimen is done here in the event that a duplicate is found.

22. Ervatamia pauciflora Ridl., J. Straits Branch Roy. Asiat. Soc. 86: 299 (1922); Ridley, Fl. Malay Penins. 2: 342 (1923). - TYPE: Peninsular Malaysia, Selangor, Ginting [Genting] Sempah, H.N. Ridley, H.C. Robinson \& C.B. Kloss s.n. (lectotype K [K000857404], designated here by Middleton; isolectotypes BM [BM001014004], K [K000857403]). = Tabernaemontana corymbosa Roxb. ex Wall. 
Leeuwenberg (1988) effectively lectotypified (corrected from 'holotype') the supposed SING duplicate of the type collection. However, this specimen cannot be found and may never have been in SING. Instead, a duplicate in $\mathrm{K}$ is designated here.

23. Finlaysonia obovata Wall., Pl. Asiat. Rar. 2: 48 t. 162 (1831); King \& Gamble, J. Asiat. Soc. Bengal, Pt. 2, Nat. Hist. 74(2): 513 (1908); Ridley, Fl. Malay Penins. 2: 373 (1923) - TYPE: India, Sundarbans, 23 Sep 1800, F. Buchanan-Hamilton 757 (lectotype E [E00174007], designated here by Rodda).

No type is clearly indicated in the protologue of Finlaysonia obovata Wall., but there is a direct reference to "Gurua obovata Herb. Hamilt." (a nom. nud.) and "Crescit ad litora aestuariorum Gangis, Irawaddi et fluminum Martabaniae...". Specimen Buchanan-Hamilton 757 [E00174007], labelled Gurua obovata, is therefore selected as lectotype. Specimen K-W 4466B from Sundarbans (Ganges estuary), collected on 23 Sep 1800 and bearing Hamilton's name Gurua obovata [K001039058] is very likely a duplicate of Buchanan-Hamilton 757 as both were collected on the same day. Specimen K-W 4466A [K001039057] is from River Martabamiae and remains therefore a syntype.

24. Gymnanthera nitida R.Br., Prodr. 464 (1810). - TYPE: Australia, Queensland, island a [Sweer's Island], Gulf of Carpentaria, 17 Nov 1802, R. Brown 2869 (lectotype BM [BM000020701], first step designated by Forster (1991), second step designated here by Rodda; isolectoypes BM [BM000020702], CANB [CANB278899], $\mathrm{K}[\mathrm{K} 000910016, \mathrm{~K} 000910017]) .=$ Gymnanthera oblonga (Burm.f.) P.S.Green

Forster (1991) mentioned two BM sheets as lectotype of Gymnanthera nitida R.Br and, therefore, a second-step lectotypification is necessary. The better specimen [BM000020701] is here designated as lectotype.

25. Gymnema finlaysonii Wight, Contr. Bot. Ind. 46 (1834); Rintz, Blumea 26: 65-79 (1980a). - Gongronema finlaysonii (Wight) Decne. in A.DC., Prodr. 8: 625 (1844). - TYPE: China or Singapore (or Thailand), Finlayson s.n, Wall. Asclep. 143 [= Wall. Cat. 8196] (lectotype K [K000872792] (ex herb. R. Wight Prop.), designated here by Rodda; isolectoype K [K001129203]). = Sarcolobus globosus Wall. subsp. globosus, fide Rintz (1980a).

Noltie (2005) clarified that Gymnema finlaysonii Wight was based on Wall. Asclep. 143 [= Wall. Cat. 8196], a specimen collected by Finlayson. In Wight's personal herbarium, now at $\mathrm{K}$, there is a duplicate of Wall. Asclep. 143 bearing a partial description and flowers sketches in Wight's hand that is therefore selected as lectotype. 
26. Gymnema wallichii Wight, Contr. Bot. India 46 (1834). - Gongronema wallichii (Wight) Decne. in A.DC., Prodr. 8: 624 (1844); King \& Gamble, J. Asiat. Soc. Bengal, Pt. 2, Nat. Hist. 74(2): 542 (1908). - TYPE: Singapore, September 1822, Wall. Asclep. 135a [= Wall. Cat. 8195B] (lectotype K [K001129202], designated here by Rodda; isolectotype E [E00288666])

Noltie (2005) clarified that original materials for Gymnema wallichii Wight are Wall. Asclep. 135a [= Wall. Cat. 8195B] and Wall. Asclep. 135b [= Wall. Cat. 8195A]. No specimens belonging to Wight's private set of Wallich specimens have been found but one sheet of each of the two collections is present in K-W. Wall. Asclep. 135a [= Wall. Cat. 8195B] [K001129202] from Singapore is therefore selected as lectotype. One sheet of the syntype Wall. Asclep. 135b [= Wall. Cat. 8195A] is present at K [K001129201]).

27. Leptostemma Blume, Bijdr. Fl. Ned. Ind. 16: 1057 (1826). - TYPE: Leptostemma hirsutum Blume, designated here by Rodda = Dischidia $\mathrm{R} . \mathrm{Br}$.

Following Omlor (1998) and Hoffman et al. (2004) the type of Leptostemma Blume has not been designated. Leptostemma hirsutum Blume = Dischidia hirsuta (Blume) Decne. is therefore designated as the type of the genus.

28. Leptostemma fasciculatum Blume, Bijdr. F1. Ned. Ind. 16: 1058 (1826). - Dischidia fasciculata (Blume) Decne. in A.DC., Prodr. 8: 623 (1844). - TYPE: "in montosis Pantjar Provinciae Buitenzorg” (lectotype P [P00218707], designated here by Rodda). = Dischidia hirsuta (Blume) Decne., fide Rintz (1980b).

Rintz (1980b) indicated the type of Leptostemma fasciculatum Blume as "Java, Blume (L)". There is no specimen in L that can be identified as original material of Leptostemma fasciculatum. In P there is one specimen labelled in Blume's hand as Leptostemma fasciculatum sent from Blume to Decaisne in 1836 [P00218707] that is here designated as lectotype.

29. Leptostemma hirsutum Blume, Bijdr. Fl. Ned. Ind. 16: 1058 (1826). - Dischidia hirsuta (Blume) Decne. in A.DC., Prodr. 8: 632 (1844). - TYPE: Java, C.L. Blume s.n. (lectotype L [L.2725198], first step designated by Rintz (1980b), second step designated here by Rodda; isolectotypes L [L.2725194, L.2725195).

Blume only indicated under Leptostemma hirsutum Blume "circa Kuripan Provinciae Buitenzorg". Rintz (1980b) indicated its type as "Java, Blume s.n. (L)" which should be considered an effective lectotypification under Art 7.11 and 9.10 of the ICN (Turland et al., 2018). No specimens can be located in L with the locality "Kuripan" 
and no single specimen can be identified as Rintz's chosen lectotype "Java, Blume s.n. (L)". Three specimens are extant in L identified in Blume's hand as Leptostemma hirsuta [L.2725198, L.2725194, L.2725195] but these are from Salak. They are, however, to be considered as Blume's original material for Leptostemma hirsutum and likely the materials mentioned by Rintz with an erroneous locality. The duplicate [L.2725198] is fertile and well preserved and therefore here designated as lectotype. There is also a specimen at P [P00218706] labelled in Decisne's hand as sent by Blume in 1836 but it only bears Java as the locality and may not be a duplicate of the sheets collected from Salak.

30. Leuconotis maingayi Dyer ex Hook.f., Fl. Brit. India 3: 628 (1882). - TYPE: Singapore, A.C. Maingay 3359 (Kew distribution 935) (lectotype K [K000832858], designated here by Middleton; isolectotype K [K000832859]). = Leuconotis griffithii Hook.f.

In Middleton $(2007,2011)$ 'Maingay KD 935' was cited as a 'holotype' of the name. A second specimen of this collection has now been seen in Kew and the better specimen is selected here as lectotype.

31. Sarcolobus banksii Schult. in Roemer \& Schultes, Syst. Veg. 6: 58 (1820). - TYPE: Indonesia, Java, Prinses island, J. Banks \& D. Solander s.n (lectotype BM [BM001014184], first step designated by Rintz (1980a), second step designated here by Rodda; isolectotype BM [BM001014185]). = Sarcolobus globosus Wall. subsp. globosus fide Rintz (1980a).

Rintz (1980a) indicated Banks \& Solander s.n (BM) as "type" of Sarcolobus banksii Schult. effecting a lectotypification under Art 7.11 and 9.10 of the ICN (Turland et al., 2018). However, two duplicates are present at BM and the better one [BM001014184] is here selected as lectotype.

32. Tabernaemontana cirrhosa Blanco, Fl. Filip. 115 (1837). - TYPE: Philippines, Capiz Province, Panay, May-June 1918, M. Ramos \& G. Edano 31503 (neotype K, designated here by Rodda; isoneotype P [P04241003]). = Finlaysonia obovata Wall., fide Merrill (1918).

Lacking an "illustrative specimen" for Tabernaemontana cirrhosa Blanco that would otherwise be a preferred choice for a neotype (Nicolson \& Arculus, 2001), Ramos \& Edano $31503(\mathrm{~K})$ is designated as the neotype for Tabernaemontana cirrhosa. 
33. Tylophora tenuis Blume var. ovata Miq., Fl. Ned. Ind. 2: 489 (1856). - TYPE: Indonesia, Java, Blambangan, T. Horsfield s.n. (lectotype BM, designated here by Rodda). = Vincetoxicum flexuosum (R.Br.) Kuntze var. tenuis (Blume) Schneidt, Meve \& Liede, fide Liede-Schumann \& Meve (2018).

Tylophora tenuis Blume var. ovata Miq. was described from a Horsfield collection from Blambangan. Liede-Schumann \& Meve (2018) did not trace it. A suitable lectotype has now been located at BM.

\section{New combination in Secamone}

Secamone maingayi (Hook.f.) Rodda comb. nov.

Genianthus maingayi Hook.f., F1. Brit. India 4(10): 16 (1883); King \& Gamble, J. Asiat. Soc. Bengal, Pt. 2, Nat. Hist. 74(2): 525 (1908); Ridley, Fl. Malay Penins. 2: 378 (1923). - TYPE: Singapore, Sep 1867, A.C. Maingay 2678 (Kew Distribution 1106) (lectotype K [K000910088], designated by Klackenberg (1995); isolectotypes $\mathrm{K}$ [K000910090], L [L0004301]).

ACKNOWLEDGEMENTS. Financial support was received from the National Parks Board (Singapore), which sponsored numerous herbarium study trips to Asian and European institutions. The curators of all herbaria mentioned in the text are thanked for providing images of specimens or assisting with loans and visits. We thank Jana Leong-Škorničková for overseeing the editorial work for this paper.

\section{References}

Brown, R. (1810). On the Asclepiadeae, a natural order of plants separated from the Apocyneae of Jussieu. Mem. Wern. Nat. Hist. Soc. 1: 12-478.

Decaisne, J. (1844). Asclepiadaceae. In: Candolle, A.L.P.P. de (ed) Prodromus Systematis Naturalis Regni Vegetabilis, vol. 8, pp. 490-684. Paris: Fortin, Masson et sociorum

Fischer, C.E.C. (1932). The Koenig Collection in the Lund Herbarium. Bull. Misc. Inform. Kew 1932: 49-76.

Forster, P.I. (1991). A taxonomic revision of Gymnanthera R.Br. (Asclepiadaceae: Periplocoideae) in Australia. Austral. Syst. Bot. 4: 563-569.

Hoffman, C, van Donkelaar, R \& Albers, F. (2004). Dischidia. In: Albers, F. \& Meve, U. (eds) Illustrated Handbook of Succulent Plants: Asclepiadaceae. Springer-Verlag Berlin Heidelberg.

Huber, H. (1973). Apocynaceae, Periplocaceae and Asclepiadaceae. In: B.A. Abeywickrama (ed.) A revised handbook to the flora of Ceylon, vol. 1, pt. 1, pp. 1-57. Colombo: University of Sri Lanka Press.

Klackenberg, J. (2001). Notes on Secamonoideae (Apocynaceae) in Africa. Adansonia, ser. 3, 23: $317-335$. 
Klackenberg, J. (2004). A new species of Secamone (Apocynaceae, Secamonoideae) from Borneo. Blumea 49: 129-133.

Leeuwenberg, A.J.M. (1988). Series of revisions of Apocynaceae XXI. Notes on Tabernaemontaneae. Agric. Univ. Wageningen Pap. 87-5: 1-60.

Leeuwenberg, A.J.M. (2003). Series of revisions of Apocynaceae LIII. Melodinus. Syst. \& Geogr. Pl. 73: 3-62.

Liede, S. (1999). The genera Cynanchum and Vincetoxicum (Apocynaceae-Asclepiadoideae) in Malesia. Blumea 44: 471-495.

Liede-Schumann, S. \& Meve, U. (2018). Vincetoxicum (Apocynaceae-Asclepiadoideae) expanded to include Tylophora and allies. Phytotaxa 369: 129-184.

Merrill, E.D. (1918). Species Blancoanae. Manila: Manila Bureau of Printing.

Middleton, D.J. (2007). Apocynaceae, subfamilies Rauvolfioideae and Apocynoideae. Flora Malesiana, ser. 1, Seed Plants, vol. 18. Leiden: National Herbarium Nederland.

Middleton, D.J. (2011). Apocynaceae, subfamilies Rauvolfioideae and Apocynoideae. Flora of Peninsular Malaysia, ser. 2, Seed plants, vol. 2. Kepong, Kuala Lumpur: Forest Research Institute Malaysia.

Nicolson, D.H. \& Arculus, D. (2001). Candidates for neotypification of Blanco's names of Philippine plants: specimens in the U.S. National Herbarium. Taxon 50: 947-954.

Noltie, H.J. (2005). The Botany of Robert Wight. Regnum Vegetabile, vol. 145. Ruggell: A.R.G. Gantner Verlag.

Omlor, R. (1998). Generische Revision der Marsdenieae (Asclepiadaceae). Aachen: Shaker Verlag.

Panigrahi, G. (1986). Nomenclature and distribution of Dischidia rafflesiana (Asclepiadaceae). Bangladesh J. Bot. 15: 195-198.

Rheede, H. A. (1689). Hortus Indicus Malabaricus, vol. 9. Amsterdam.

Rintz, R.E. (1980a). A revision of the genus Sarcolobus (Asclepiadaceae). Blumea 26: 65-79.

Rintz, R.E. (1980b). The Peninsular Malayan species of Dischidia (Asclepiadaceae). Blumea 26: 81-126.

Surveswaran, S., Sun, M.E.I., Grimm, G.W., Liede-Schumann, S. (2014). On the systematic position of some Asian enigmatic genera of Asclepiadoideae (Apocynaceae). Bot. J. Linn. Soc. 174: 601-619.

Turland, N.J., Wiersema, J.H., Barrie, F.R., Greuter, W., Hawksworth, D.L., Herendeen, P.S., Knapp, S., Kusber, W.-H., Li, D.-Z., Marhold, K., May, T.W., McNeill, J., Monro, A.M., Prado, J., Price, M.J. \& Smith, G.F. (eds) (2018). International Code of Nomenclature for algae, fungi, and plants (Shenzhen Code) adopted by the Nineteenth International Botanical Congress Shenzhen, China, July 2017. Regnum Vegetabile 159. Glashütten: Koeltz Botanical Books.

Van Steenis-Kruseman, M.J. (1950). Malaysian plant collectors and collections: being a cyclopaedia of botanical exploration in Malaysia and a guide to the concerned literature up to the year 1950. In: van Steenis, C.G.G.J. (ed.) Flora Malesiana, ser. 1, Seed Plants, vol. 1, pp. 1-606. Jakarta: Noordhoff-Kolff. 